\title{
Bir Aydınlanma Şahsiyeti ve Amerikan Karakterinin İnşacısı Olarak Benjamin Franklin
}

\section{Mümin Köktaş}

Öz:Benjamin Franklin Amerika'nın kuruluş döneminin en önde gelen düşünür ve siyaset insanlarından birisidir. Amerika tarihi bakımından neredeyse mitik bir statüye sahiptir. Boston'da doğmuş ve sadece iki yıl eğitim almış birisi olmasına rağmen yaşamının sonunda oldukça ünlü bir Amerikalı olması nedeniyle Amerikan rüyasının bir temsilcisi olarak görülmüştür. Ne yazık ki Franklin çalışmaları uzun yıllar boyunca bu mitsel bakıș açısıyla sürdürülmüștür. Ayrıca Franklin entelektüel olarak bazı așırı genellemelerin hedefi olmuştur. Bazen kapitalizmin ve bencil biriktirme arzusunun sözcüsü bazen de ruhsuz ve mekanik bir dünyanın temsilcisi olarak görülmüştür. Buna rağmen, Amerika'nın kurucu babalarından birisi olarak Franklin'in Amerika'nın kuruluşuna katkısı ve Aydınlanma hareketi içerisindeki yeri daha önemli konulardır. Franklin üzerine gerçekleştirilecek çalışmalar ayrıca Aydınlanma düşüncesinin farklı veçhelerinin anlaşılması açısından Aydınlanma çalışmalarını derinleştirecektir. Amerika, Aydınlanmanın teorik ve felsefi boyutlarında vaatkâr olmasa dahi Aydınlanmanın pratiği açısından oldukça önemli bir deneyimdir. Bu deneyimin görüleceği temel iki boyut ise ahlak felsefesi ve siyasal düşünce olacaktır. Bu amaçla, bu makalede Franklin'in Aydınlanma düşüncesindeki yeri ve Amerika'nın kuruluşundaki katkısı tartışılacaktır.

Anahtar Kelimeler: Benjamin Franklin, On sekizinci Yüzyıl, Amerikan Aydınlanması, Amerikan Devrimi, Kurucu Babalar

\footnotetext{
1 Dr. Öğretim Üyesi, Ankara Yıldırım Beyazıt Üniversitesi, Siyasal Bilgiler Fakültesi Siyaset Bilimi ve Kamu Yönetimi Bölümü, mkoktas@gmail.com, Orcid No: https://orcid.org/0000-0002-7559-9025.
} 


\title{
Benjamin Franklin as an Enlightenment Personality and the Builder of the American Character
}

\begin{abstract}
Benjamin Franklin is one of the foremost thinkers and politicians of the eighteenth-century America. He has a mythical legacy in terms of American history. He has been perceived as a person who represents the American dream in one sense that he was born in Boston and studied for only two years, but at the end of his life, he had a great reputation. Unfortunately, Franklin studies have long been maintained with this mythical point of view. Besides, Franklin was intellectually the target of some extreme generalities. Sometimes he was regarded as a spokesman for capitalism and selfish accumulation desire, and sometimes as a representative of a senseless and mechanical world. Yet, as one of the American founding fathers, Franklin's intellectual contribution to the American founding and his place in the Enlightenment are more important. Working on Franklin will also further deepen the Enlightenment studies in understanding the different aspects of Enlightenment thought. For this purpose, Franklin's place in the thought of the Enlightenment and his contribution to the American founding will be discussed in this article.

Key words: Benjamin Franklin, Eighteenth-Century, American Enlightenment, American Revolution, Founding Fathers
\end{abstract}

\section{Giriş}

Benjamin Franklin Amerika'nın kuruluş döneminin en önde gelen düşünür ve siyaset insanlarından birisidir. Amerika tarihi bakımından neredeyse mitik bir statüye sahiptir. Sıkı çalışırsan, kurallara göre oynarsan başaracaksın biçiminde özetlenebilecek Amerikan rüyasının müjdecisi olarak bilinir² (Houston, 2004: xiv). Franklin, "Kurucu Babalar” arasında en cana yakın ve popüler bir kişi olarak görülmekle birlikte aynı zamanda en küçümsenen insanlardan da biri olmuştur (Wood, 2004: 4). Franklin 1706 yılında Boston'da doğmuş3 ve 1790 yılında

\footnotetext{
${ }^{2}$ Başarıya yönelik bu vurgu nedeniyle, Mark Twain (1870) Franklin örneğinin sonraki Amerikan gençleri için ağır bir yük oluşturduğunu ifade eder.

${ }^{3}$ Franklin'in aile kökenleri İngiltere'den gelir. Ortaçağlar boyunca İngiltere'nin kırsal bölgelerinde zengin ve mülkiyet sahibi ancak aristokrasinin üyesi olmayan bir sınıf oluşmaya başlamıştı. Toprak sahibi bu orta sınıf üyeleri özgür insan anlamına gelen Franklin'ler olarak adlandırılmaktaydı. Franklin'in büyük büyük dedesi, Franklin soyadını 1540
} 
Philedelphia'da ölmüștür. 1714-16 yılları arasında Boston Gramer Okulu'na ve George Brownell'in İngilizce bölümüne kayıt yaptırmış, ancak okul maliyetleri nedeniyle sadece iki yıl devam edebildiği okulunu tamamlayamamıştır. Resmi olarak sadece iki yıl eğitim almakla birlikte, Franklin hayatı boyunca öğrenme aşkını kaybetmemiştir. ${ }^{4}$ Öldüğü zaman başarılarıyla dünya çapında bir üne kavuşmuştur. Jefferson (1853: 71), Franklin'den “zamanımızda kimse ondan daha önemli keşifler yapmamıştır, felsefeyi daha zenginleştirmemiştir, doğa olgusuna daha yaratıcı çözümler bulmamıştır” biçiminde söz etmiş, Hume (1762) ise, Franklin'e yazdığı bir mektupta şunları ifade etmiştir: “Amerika bize altın, gümüş, şeker, tütün, çivit gibi birçok güzel ürün göndermektedir. Ancak sen Amerika'ya borçlu olduğumuz ilk filozof ve hatta ilk büyük yazın insanısın." Fransız düşünür Condorcet ise Franklin'i şöyle tarif etmiştir: "Tek kelimeyle onun siyaseti, aklın gücüne ve erdemin gerçekliğine inanan bir insanın siyaseti idi” (Stourzh, 2007: 29).

yıllarında kullanmaya başlamıştı. Franklinlerin Amerika'ya göç etme nedeni hem püritenlerin İngiltere'de yaşadığı sorunlar nedeniyle dinin özgürce yaşanması arzusu hem de ekonomik sıkıntılardır (Isaacson, 2014: 7, 11).

4 Franklin erken yaşlarından itibaren meslek olarak matbaacılık ve yayın dünyası içerisinde bulunan bir yazar olmuştur. 1722 yılında daha 16 yaşında iken Sessiz lyilik (Silence Dogood) takma adılla New-England Courant gazetesine 14 mektup yayımlatmıştır. 1724 yılında Londra'ya gitmiş, burada William Wollaston'un Doğa Dininin Tasviri (The Religion of Nature Delineated, 1722) adlı kitabına yanıt olarak Özgürlük ve Gereklilik, Haz ve Acı Üzerine Bir Deneme (Dissertation on Liberty and Necessity, Pleasure and Pain, https://founders.archives.gov/documents/Franklin/01-01-02-0028) adlı eserini yazmış, bu metin üzerine Bernard Mandeville ile tanıştırılmıştır. Franklin bu metninde deizm tartışmalarının ötesine geçerek materyalist ve ateist bir tavır sergileyerek, özgür iradeyi reddetmiş, erdem ve kötülük arasında bir ayrım olmadığını, haz ve acının her şeyi belirlediği düşüncelerini ileri sürmüștür. Ancak sonrasında bu tavrının bireylere ve toplumlara mükemmelleșme yolunda bir katkı sağlamayacağını düşündüğü için bu fikrinden vazgeçmiş ve denemelerinin bulabildiği kadar kopyasını yok etmeye çalıșmıştır. Bununla birlikte, Stourzh'un (2007: 31) ifade ettiği gibi, bu metin Franklin'in Presbiteryen aile geçmişinin izlerini üzerinden attığı ve düşüncesinin sekülerleşmesinin tamamlandığı anlamına gelir. Franklin Philadelphia'ya döndükten sonra 1727 yılında üyeleri çoğunlukla yerel esnaftan oluşan ve kişiselgelişmeyi hedefleyen Junto adlı bir kulüp kurmuştur. Cuma akşamları toplanan bu kulüpte ahlak, felsefe, siyaset ve ticaret konuları tartışılmıştır. 1729 yılında American Weekly Mercury'de Iş̧güzar (Busy-Body) serisiyle yazılar kaleme almış, ayrıca Kâğıt Paranın Doğası ve Gerekliliği Hakkında Mütevazi Bir Araștırma adlı denemesini yayımlamıştır. Yine aynı yıl iflas etmek üzere olan Pennsylvania Gazette'yi satın almış ve yaklaşık 10 yıl içerisinde bu gazeteyi Amerikan kolonilerinde en çok okunan gazeteye dönüştürmüştür. 1730 yılında Pennsylvania kolonisinin resmi matbaacısı olmuş, sonraki yıl masonlara katılmış ve Amerika'daki ilk üyelikle çalışan kütüphanesi olan Philadelphia Kütüphane Topluluğu'nu kurmuştur. 1732'de Poor Richard's Almanack'larını yayımlamaya başlamış ve 1757 yılına kadar yıllık olarak buna devam etmiştir. Mason locasında büyük üstat olduktan sonra 1734 yılında Amerika'da basılan ilk mason kitabı olan James Anderson'un Masonların Anayasaları adlı kitabını yayımlamıştır. Yaklaşık olarak 1732 'den beri kiliseye gitmeyi bırakmasına rağmen, pratik ahlak üzerinde duran, inancı bir araç, ahlak ve erdemi ise bir amaç olarak gören Samuel Hemphill'in vaazlarını dinlemek üzere kiliseye gitmiş, dini çevrelerin Ortodoks olmamakla suçladığı Hemphill'i savunmak için de bazı risaleler yazmıştır. Bu risaleler dini meselelerde Franklin'in vicdan özgürlüğünü savunduğunu gösterir. 1743 yılında Amerika'daki Britanya Plantosyalarında Faydalı Bilginin Geliştirilmesi Üzerine Bir Öneri'yi yayımlamış (bu yazı Amerikan Felsefe Derneği'nin kurulmasında etkili olmuştur), Philadelphia Akademisi ve Koleji (sonrasında bu Pennsylvania Üniversitesi olmuştur) konusunda bir taslak çalışması yapmıştır. 1759 yılında İskoçya'daki St. Andrews Üniversitesi'nden fahri doktora almış ve bundan sonra Dr. Franklin olarak anılmıştır. Bu İskoçya ziyareti sırasında ayrıca Adam Smith, William Robertson ve Lord Kames gibi İskoç Aydınlanması'nın öncü isimleriyle tanıșmıștır. 1762 yılında bu sefer Oxford Üniversitesi'nden fahri doktora almıştır. Koloni dönemi Pennsylvaniasında ve devrim dönemi Amerikasında siyasal bir lider olarak, koloniler arasındaki sorunları tartışmak üzere New York - Albany'de düzenlenen toplantıya katılmış, burada reddedilen bir Birlik Planı önermiş, Amerikan Bağımsızlık Bildirgesi'nin kaleme alınmasına yardım etmiş, Fransa ve Britanya ile yapılacak görüşmelerde Amerikan kolonilerini temsil etmiş ve Anayasa Konvansiyonu'na katılmıştır. Bkz. Carla Mumford (Ed.) (2008), The Cambridge Companion to Benjamin Franklin, Cambridge, Cambridge University Press. Franklin öldüğünce arkasında İngilizce, Fransızca, İtalyanca, Latince, İspanyolca ve Almanca'dan oluşan 4276 ciltlik bir kütüphane bırakmıştır (Houston, 2004: xv). 
Franklin'in deneysel bilimlerle özel bir ilgisi olmuştur. Elektrik ${ }^{5}$ üzerine olan çalışmalarıyla zamanında tanınmıştır ve Londra'daki Kraliyet Akademisi'ne üye seçilmiştir (Elektrik Üzerine Deneyler ve Gözlemler başlıklı çalışması bu akademi tarafından yayımlanmıştır, beş İngilizce, üç Fransızca, bir Almanca ve bir ittalyanca edisyonu yapılmıştır), Kuzey Amerika'da ilk bilimsel topluluğun, kütüphanenin, itfaiye teşkilatının, hastanenin kurulmasına öncülük etmiştir, paratoneri, çift odaklı gözlükleri, verimli bir şekilde çalışan odun sobasını icat etmiştir (Houston, 2004: xiii). Franklin ayrıca yaşamının son yıllarında Rusya Bilimler Akademisi'ne de üye seçilmiştir.

Nüktedan, zarif ve idrak sahibi bir kişi olarak Franklin farklı edebi metinler kaleme almıştır. Franklin'in yazı biçimi ve ahlaki kanaatleri Londra'da Joseph Addison ve Richard Steele tarafından çıkarılan Spectator adlı kahve evi dergisinden oldukça etkilenmiştir (Fea, 2011: 130). Kendi yazı stili için bu yazarları bir model olarak almıştır (Gaustad, 2004:11). Üretken bir yazar olmakla birlikte Franklin'in kaleme aldığı tek kitap kendi Autobiography'sidir (tamamlanmamıştır) ve bu metin Amerikan edebiyatının bir klasiği olarak değerlendirilir. İlk ve hâlen geçerli klasik Amerikan başarı öyküsünün en önemli örneğidir. Yoksul bir çocuğun nasıl zamanının en ünlü Amerikalısı haline geldiğini, Franklin kendi hikâyesiyle anlatır (Smith, 2016: 109). Autobiography'yi Franklin 65 yaşında iken 1771 yılında yazmaya başlamış, 1780’li yıllara kadar yazmaya devam etmiştir. Biyografi 1706 yılında Boston'da doğumuyla başlar, 1757 yılında sona erer. Bu nedenle Franklin'in 1790 yılında öldüğü göz önünde bulundurulduğunda eser tam bir biyografi değildir ve 1818 yılına kadar da yayımlanmamıştır. Autobiography'yi oğluna hitaben yazmış olmakla birlikte, Franklin gelecek nesiller tarafından okunmasını tahayyül etmekteydi (Smith, 2016: 110). Diğer bir ifadeyle Franklin'in farklı duygularla bu metni kaleme almıştır: Oğluna kendi aile tarihini anlatmıştır, düşmanlarına karşı kendi ününü haklılaştırmaya çalışmıştır, dünyada sahip olduğu başarının keyfini kayda geçirmiştir ve kendi hikâyesinin özellikle genç okuyucular için ahlaki ve siyasal bir eğitim olanağı sunmasını ummuştur (Houston, 2004: xvii).

Bütün bu bilgilerin ışığında, Franklin, yine de soyut veya sistematik bir düşünür olarak değerlendirilemez. Yale Üniversitesi tarafından 47 cilt olarak planlanan ve basılan Benjamin Franklin Yazıları (The Papers of Benjamin Franklin) incelendiğinde, Franklin'de rafine bir adalet nosyonu ya da insan doğası teorisi bulmak kolay değildir. Para politikasından cinsel davranışlara, iş ahlakından köleliğin ${ }^{6}$ kötülüklerine kadar oldukça geniş bir yelpaze sunan bu metinler dikkate değer eleştirel bir zihinle karşı karşıya olduğumuzu bize gösterir. Bununla

\footnotetext{
${ }^{5}$ 18. Yüzyıl bağlamında Franklin'in elektrik üzerine çalışmaları konusunda bkz. Michael B. Schiffer (2003), Draw the Lightning Down: Benjamin Franklin and Electrical Technology in the Age of Enlightenment, Berkeley and London: University of California Press

${ }^{6}$ Franklin 1787 yılında kölelik karşıtı faaliyetlerini yoğunlaştırmış ve 1789 yılında Kongre'ye hitaben yazılmış ilk kölelik karşıtı metni imzalamış, 1790 yılında da köleliğin ve köle ticaretinin yasaklanması amacıyla Kongre'ye dilekçe vermiştir. Bu bağlamda Franklin ilk başlarda köleliğe ekonomik verimsizlik açısından baktığı, sonrasında ahlaki temelde köleliğe itiraz ettiği görülmektedir (Houston, 2008: 222).
} 
birlikte, muhtelif yazarlar tarafından Franklin; Püriten, deist, ateist, Newtoncu bir deneyci, Aydınlanma rasyonalisti, demokrat bir halkçı, liberal bireyci, küçük burjuva, ilkeli pragmatist, fırsatçı bir kötü adam olarak da tasvir edilmiştir (Houston, 2004: xiii- xiv). Bu nedenle tek bir Franklin portresi çizmek neredeyse imkânsızdır. Yaşadığı dönemin hareketliliği göz önünde alındığında tüm bu farklı Franklin tasvirlerinin gerçekliğin sadece tek bir yönünü vurgulamaya çalıştığı belirtilebilir.

\section{Franklin ve Ahlaki Yapının Dönüşümü}

Aydınlanma çağı, Reform hareketleri sonrası Batı toplumlarının yaşadığı krizlere bir yanıt bulma arayışıdır. Bu krizin en önemli veçhelerinden birisi din ve ahlak arasında kurulan zorunlu bağlantının kırılmış olmasıydı. Bu açıdan ahlakın temellerinin belli bir din anlayışına bağlı olarak inşa edilmesi konusunda bir uzlaşma artık mümkün değildi (Köktaş, 2018: 31). Benjamin Franklin, özellikle Autobiography'sinde bu çerçevede Amerika bağlamında söz konusu ahlaki krize seküler yanıtlar vermeye çalışmıştır.

Franklin'in Autobiography'sinde en dikkat çekici kısım bireysel ahlakın ve erdemlerin geliştirilmesine yönelik önerdiği plandır. Çünkü Franklin açısından ahlaki olarak önemli olan sözler değil eylemlerdir. Kendi ifadesiyle "Kelimeler bir insanın zekâsını ama eylemler onun anlamını gösterir" (Franklin 1749). Bununla birlikte, Franklin (2004: 68) önceleri düşündüğünden daha zor bir görev üstlendiğinin farkına vardığını belirtir. Insanın eğilimleri ve alışkanlıkları her zaman doğru davranışa yol açmıyordu. Bu nedenle bir yöntemle doğru davranışların edinilmesi ve yanlış olanların terk edilmesi gerekiyordu. Buna göre, belli bir zaman dilimi için bir erdem alınır, o erdem iyice özümsenene kadar sistematik olarak onun üzerinde çalışılır ve sonrasında diğer erdeme geçilir. Franklin bu bağlamda on üç erdemi liste halinde sunar, her biri üzerinde bir hafta durur, bir yıllık zaman dilimi içerinde dört tur yapılacağını söyleyerek ahlaki bir mükemmellik elde edilebileceğini savunur (Smith, 2016: 120). Erdeme sahip olmanın araçlarını ve biçimlerini gösterdiği için, Franklin kendi kitabının "erdem sanatı" olarak adlandırılabileceğini ileri sürer (Franklin, 2004: 75). Franklin'e göre bu erdemler bir amaç değil, araçtır. Asıl olan mutluluktur (Anderson, 2008: 24). Franklin'in on üç erdemi ve bunlar için gösterdiği kaideler şöyledir:

1. Ölçülülük

Bıkıncaya kadar yemeyin. Sarhoş olacak kadar içmeyin.

2. Sessizlik

Başkalarına ya da kendinize yararı olmayacaksa konuşmayın.

3. Düzen

Her şey yerli yerinde dursun. İşinin her bir kısmına özen gösterip zaman ayır. 


\section{Kararlılık}

Ne gerekiyorsa yapmaya azimli olun. Karar verdiğiniz şeyi başarısız olmadan gerçekleştirin.

\section{Tutumluluk}

Masraflı olmayın, başkalarına veya kendinize iyi şeyler yapın, hiçbir şeyi boşa harcamayın.

6. Çalışkanlık

Zamanı israf etmeyin. Her zaman işe yarar bir şeyde çalışın. Gereksiz tüm işlemlere son verin.

\section{Dürüstlük}

Zarar verecek bir biçimde aldatmayın. Masum ve adil bir şekilde düşünün. Konuşmanız gerekirse buna göre konuşun.

\section{Adalet}

Zarar vererek ya da göreviniz olan faydalı davranışları ihmal ederek yanlış yapmayın.

9. Ilımlılık

Aşırılıktan kaçının. Hak ettiklerini düşünseniz bile tahammüllü olun.

10. Temizlik

Bedende, elbiselerde veya ikamet yerlerinde pisliğe hoşgörülü olmayın.

11. Dinginlik

Önemsiz şeylerden ya da yaygın veya kaçınılmaz olaylardan endişelenmeyin.

12. iffet

Sağlık veya üreme dışında cinsel hazların peşinden nadiren gidin. Kendinizin veya başkasının huzurunun veya itibarının zedelenmesine izin vermeyin.

13. Tevazu

İsa'yı ve Sokrates'i örnek alın. (Franklin, 2004: 68-9).

Bu listede dikkat çekici unsurlardan biri temizlik, sessizlik ve çalışkanlık gibi klasik veya Rönesans etik anlayışlarında yer almayan unsurların Franklin tarafından kendi sistemine dâhil edilmesidir. Ayrıca cesaret, bilgelik, dostluk, yüce gönüllülük, gurur gibi Aristocu erdemler bu listede yoktur. Aristocu cömertlik erdemi ise tutumlulukla yer değiştirmiştir. Diğer taraftan iman, umut, 
merhamet gibi Hristiyan erdemleri de ihmal edilmiştir. Şan, asalet veya azizlik gibi erdemlerin de listede yer almaması bir açıdan ahlaki mükemmelliğe çok az insanın erişebileceğini gösterir. Bununla birlikte, Franklin'in listesi gündelik ve faydalı mesleklerle uğraşan insanların elde edebileceği erdemlerdir (Smith, 2016: 121; Pangle, 2007: 73). Diğer taraftan, Franklin her ne kadar planının faydalılığından ve kesinliğinden emin olsa da kendi kusurluluklarının da farkındadır (Franklin, 2004: 74). "Kurucu babalar" içerisinde bu nedenle insan doğasını en iyi kavrayanlardan biri Franklin olmuştur. İnsan davranışının tüm taraflarını görebilecek ve başka bakış açılarını takdir edebilecek bir yetiye sahiptir (Wood, 2004: 15). Amacı kötü alışkanlıklarını düzelterek kendini geliştirmeyi sağlamaktır; ancak insana dair bu kusurluluk vurgusu, onu, günahkâr bir insan doğası anlayışına teslim etmemiştir. Aksine başkalarının hatalarına yönelik ılımlı, hoşgörülü ve uysal bir davranış göstermesine neden olmuştur. Franklin'in bu mükemmeliyetçi olmama durumu özellikle onun listesinde on üçüncü erdem olan tevazuda açıkça görülebilir. Franklin listesini hazırlarken aslında on iki erdem olarak bunu tasarladığını, Quaker bir arkadaşının kendisine, onun genellikle kibirli bir insan olarak düşünüldüğünü söylemesi üzerine tevazuu listesine eklediğini belirtir. Franklin yine de tevazulu görünmekten daha fazla bu erdeme sahip olamadığını itiraf eder (Smith, 2016: 123). Bu noktadan bakıldığında, Franklin'in listesi bir gelişim sıralaması gösterir niteliktedir. Bir zorluk derecesine göre erdemler, ölçülülük ve sessizlikten başlayarak iffet ve tevazuya doğru ilerler (Anderson, 2008: 27).

Franklin'in ahlak anlayışı insanın mükemmelliği nosyonuna sahiptir. Bununla birlikte insanı aynı zamanda kusurlu bir varlık olarak değerlendirir. Diğer bir ifadeyle, kusurları olan bir varlık olarak insan; kendini geliştirme potansiyeline sahiptir. Bu açıdan Franklin, Aydınlanma düşüncesinin iyimserliğini ve insanın gerek bireysel gerek toplumsal olarak ilerleyebileceğini kabul ederek Aydınlanma ideasına pratik bir alan açar. İnsanın hatalarını ve kusurlarını deneme ve yanılma ile düzeltildikleri takdirde bunlar iyi bir ahlaki karakterin oluşmasına yol açacaktır. Insan eylemlerinden pişmanlık ve vicdan azabı çekmeksizin öğrenebilir ve onları iyileştirebilir. Bu noktada eğitim kavramı temel bir anlam kazanır. ${ }^{7}$ Autobiography böylece eğitimle bir insanın nasıl gelişeceğini gösteren örnek bir metin olarak okunabilir. Franklin'in ahlak üzerine düşünceleri Autobiography'nin sadece ahlak mükemmelliği bahsinde yer almaz. Poor Richard's Almanack ${ }^{8}$ yazıları, The Way to

\footnotetext{
${ }^{7}$ Aydınlanmanın eğitim üzerinden tanımlanması konusunda bkz. Moses Mendelssohn (2000), "Aydınlanma Nedir? Sorusu Üzerine (1784)", Toplumbilim, Aydınlanma Özel Sayısı, Sayı: 11, Temmuz 2000: 13-15

${ }^{8}$ Koloni dönemi Amerikasında bu almanaklar neredeyse her evde bulunmaktaydı. Almanaklar hava durumu ve önceki yılın önemli olaylarını kayda geçirmiş, ayın hareketlerini ve gel-git zamanlarını açıklamış, esprili ifadelere ve hikmetli atasözlerine yer vermiștir. Bu nedenle Franklin almanakların hem eğlendirici hem de faydalı olmasını amaçlamıştır. Nüfusun yaklaşık 15.000 olduğu bir kolonide yılda 10.000 kopya satış yapmayı başarmıştır (Gaustad, 2004: 35).
} 
Wealth 9 (1758), A Man of Sense $e^{10}$ (1735) ve The Speech of Miss Polly Baker ${ }^{11}$ (1747) makaleleri ahlak üzerine tartışmaların izlenebileceği yerlerden bazılarıdır.

Franklin'in tüm bu ahlak perspektifi elbette din ile nasıl bir ilişki kurduğu değerlendirilmeksizin anlaşılamaz. Franklin zamanının olağan seyri içinde ailesi tarafından dindar bir Presbiteryen olarak yetiştirildi. Gençliğinde, 1678 ve 1684 yıllarında iki parça halinde yayımlanan John Bunyan'ın The Pilgrim's Progress ${ }^{12}$ ve Bostonlu bir din adamı olan Cotton Mather'ın Bonifacius, or Essays to Do Good ${ }^{13}$ (1710) adlı kitaplarını okuduğunu ve bunlardan etkilendiğini belirtir (Franklin, 2004: 10). Bununla birlikte Franklin erken yaşlarından itibaren dini törenlere katılmaktan, papazların vaazlarında herhangi bir ahlak bulamadığı için imtina etti. Pazar günlerinin kendisinin için bir okuma ve çalışma günü olduğunu belirtir. Articles of Belief and Acts of Religion ${ }^{14}$ adını verdiği kendisi için ayrı bir dua metni oluşturmuş ve kişisel ibadetlerinde bunu kullanmıştır. Bazı dini ilkeleri asla terk etmediğini belirten Franklin, din anlayışı ile ilgili olarak şunları ifade eder: "Bazı dini ilkeleri asla terk etmedim. Mesela tanrının varlığından, onun dünyayı yarattığından, takdiri ilahisiyle onu yönettiğinden, insanlara iyilik etmenin tanrıya hizmette bulunmanın en uygun yolu olduğundan, ruhlarımızın ölümsüzlüğünden, bu dünyada ya da öteki dünyada bütün suçların cezalandırılacağından ve bütün erdemlerin ödüllendirileceğinden asla şüphe duymadım. Bunları her dinin temeli olarak kabul ettim ve bunlar ülkemizde bulunan her dinde mevcuttur" (Franklin, 2004: 66). Ancak, Franklin okuduğu kitaplar ile tartışmacı, alaycı ve hiciv ${ }^{15}$ sahibi karakterinin etkisiyle on beş yaşına geldiğinde vahyin kendisi dâhil şüpheler taşıdığını ve "esaslı bir deist" olduğunu ifade eder (Franklin, 2004: 46). Daha on altı yaşında iken "Sessiz İyilik" mahlasıyla yazdığı yazıda insanların Eğitim Tapınağı ile karşı karşıya geldiklerinde oraya gittiklerini ancak orada yapılan işi oldukça zor gördükleri için aylaklıklarını sürdürdüklerini ve cehalet içerisinde kalmaya devam ettiklerini yazmıştı. ${ }^{16}$ İnsanların büyük çoğunluğu ise Teoloji

\footnotetext{
${ }^{9}$ Bu metin Poor Richard's Almanack'larının Franklin tarafından yapılan bir özetidir. Kitap 40 yılda yaklaşık 145 baskı yapmış ve yedi dile çevrilmiştir (Isaacson, 2014: 100).

https://liberalarts.utexas.edu/coretexts/_files/resources/texts/1758\%20Franklin\%20Wealth.pdf

${ }^{10} \mathrm{https}: / /$ founders.archives.gov/documents/Franklin/01-02-02-0003

${ }^{11}$ https://founders.archives.gov/documents/Franklin/01-03-02-0057

${ }^{12}$ Bu metin zamanında Püritenler arasında oldukça popüler olmuştur ve İncil'den sonra en çok okunan kitaplar arasında yer almıştır. Kitabın temel konusu başlığından da görüleceği üzere ilerlemedir. Hristiyan bir karakter üzerinden bireylerin ve toplumların bilgi ve erdemlerinin nasıl ilerleme kaydedeceğini göstermeye çalışır (Isaacson, 2014: 27).

${ }^{13}$ Bu metin Püriten bir yaklaşımla insani faaliyetlerin önemi üzerinde durur ve bilimsel çalışmaları destekler. Franklin'in Sessiz lyilik (Silence Dogood) mahlası Mather'a bir gönderme yapmaktadır.

${ }^{14}$ https://founders.archives.gov/documents/Franklin/01-01-02-0032

${ }^{15}$ Franklin hiciv (satirical) yazılarına tüm yaşamı boyunca devam etmiştir. Dar görüşlülüğü yansıtan toplumsal konulardan Britanya'nın kolonilere karşı sergilediği emperyal tavırlara ve kölelik sorununa kadar birçok konuyu hicveden yazılar kaleme almıştır. Bu açıdan hicvi, erdemi yüceltmek ve kötülüğü yermek için kullanmıştır (Kerry, 2008: 37).

${ }^{16}$ Buradaki ifadeler Kant ile bir benzerlik taşır. Kant daha sonrasında yazdığı Aydınlanma Nedir? adlı ünlü makalesinde Aydınlanmayı insanın ergin olmama durumundan aklını kullanmaya cesaret ederek çıkması olarak tanımlar. Ancak bu süreç kolay değildir ve birçok insan isteyerek ergin olmama durumunda kalmaya devam eder. Bkz. I. Kant (2000), “Aydınlanma Nedir? Sorusuna Yanıt (1784)", Toplumbilim, Aydınlanma Özel Sayısı, Sayı: 11, Temmuz 2000: $17-21$
} 
Tapınağı'nda idi ve Franklin burada söz etmeye değecek bir şey bulamadığını ekler (Franklin, 1722b). Genç bir birey olmakla birlikte Franklin'in burada açıkça Aydınlanmanın dini kurumlara karşı verdiği mücadeleye katıldığı gözlemlenebilir. Zaman içerisinde Franklin alaycı, tartışmacı ve yergici üslubunu bıraktıktan sonra, deizmin öğretisinin doğru olabileceğini ancak faydalı olmadığını düşünmeye başladı. Bu aşamada, metafizik akıl yürütmelerini bir kenara bırakıp, insanlar arasındaki ilişkilerde içtenlik, samimiyet ve dürüstlüğün yaşam mutluluğunda en önemli unsur olduğunu savundu ve bu onu daha hoşgörülü bir karaktere dönüştürdü (Franklin, 2004: 46-7). Franklin'in dini toplumsal fayda açısından ele almasında özellikle 1732 yılında kaleme aldığı On the Providence of God in the Government of the World ${ }^{17}$ adlı metni önemli bir dönüm noktası olmuştur. Franklin'e göre insanların tanrıyı anlaması için Hristiyan teolojisine ya da Incil'in vahyine ihtiyaçları yoktur. Evrenin yaratıcısı olan tanrı, insan faaliyetlerine aktif bir biçimde dâhil olur. Bu açıdan Franklin'in dini kanaatleri Aydınlanmanın ahlaki ve toplumsal ilerleme arayışında dine bir alan açar (Fea, 2011: 135-6).

Franklin yaşamı boyunca dini meselelerde dogmatik bir tavır almaktan sakınmıştır. Onun dini konulardaki bu dogmatik olmama eğilimi aynı zamanda dini kurumlara ve dinin kendisine karşı da radikal olmaktan uzak ılımlı bir tavır göstermesiyle sonuçlanmıştır. Tarihçiler Franklin'in din anlayışının onun New England Kalvinizmine yönelik entelektüel hoşnutsuzluğuyla geliştiği konusunda ortak bir kanaate sahiptirler. Ona göre, Presbiteryenler teolojik inançlarını toplumun faydalanacağı bir ahlak sistemine dönüştürmekte başarısız olmuşlardı ${ }^{18}$ (Fea, 2011: 129, 137). Bu açıdan Franklin'in ilginç dostlarından birisi George Whitefield ${ }^{19}$ olmuştur. Whitefield'in okullar inşa etmesi, yetimlere bakması, köle sahiplerini eleştirmesi gibi yaklaşımları Franklin'in dinin toplumsal faydası konusunda gösterdiği yaklaşımı desteklediği için her iki kişi arasında yakın bir dostluk oluşmuştur. Franklin, Whitefield'in evanjelizmini kabul etmemiş olabilir ancak onun vaazlarındaki mesajlarının basitliğine, teolojisinin sırlarla dolu olmamasına ve dogmatik olmayan bir din anlatısına hayranlık duymuştur (Fea, 2011: 140; Gaustad, 2004: 33). Franklin Autobiography'de erken yaşlarından itibaren sahip olduğu bir fikir olarak, bilinen her dinin temelinde bulunduğunu düşündüğü bazı özellikleri belirtir: "Her şeyi yaratan tek bir Tanrı vardır. O tasarrufuyla dünyayı yönetir. Ona sevgiyle, duayla ve şükranla ibadet edilmelidir. Tanrı'ya hizmet etmenin en kabul edilebilir yolu insanlara iyilik etmektir. Ruh ölümsüzdür. Bu Tanrı ya burada ya da öteki dünyada erdemi ödüllendirecek ve kötülüğü cezalandıracaktır (Franklin, 2004: 79)." Tanrıya yönelik bu fikirleriyle Franklin ilahi bir metne gönderme yapmaksızın bir inanç sistemi önermeye çalışmıştır. Franklin 1790 yılında Yale Üniversitesi rektörü Ezra Stiles’a yazdığı bir

\footnotetext{
${ }^{17}$ https://founders.archives.gov/documents/Franklin/01-01-02-0090

${ }^{18}$ Franklin'in yerleşik dini düşünceye karşı radikal tavırlarından birisi, erdemli bir inançsızın kötü bir Hristiyan'dan önce kurtuluşa erebileceği düşüncesinde görülebilir (Franklin, 1735).

${ }^{19}$ Whitefield koloni dönemi Amerikasının en popüler vaizlerinden birisidir. George Whitefield ile ilgili olarak bkz. Thomas S. Kidd (2014), George Whitefield: America's Spiritual Founding Father, New Haven and London: Yale University Press.
} 
mektupta yukarıda belirtilen unsurları tekrarlamış ve bu ilkelerin her dinin temelinde bulunması gerektiğini savunmuştur. Bu mektupta ayrıca Nasıralı İsa'yı ahlak sistemi öneren bir kişi olarak görmekle birlikte onun tanrısallığı konusunda şüpheleri olduğunu, ancak bu konu üzerinde çalışmadığı için kesin bir dille konuşamayacağını ifade eder (Franklin, 1790). Bu nedenle Franklin'in din anlayışının doğal din olduğu belirtilebilir. Buna göre tanrı insanları sadece rasyonel değil aynı zamanda ahlaki varlıklar olarak yaratmıştır (Kelleter, 2008: 83). Dini dogmalara karşı gösterdiği bu şüpheci tavrı ile Franklin, Aydınlanma düşüncesinin bir temsilcisi olarak fayda üzerinde durmuş, pragmatizmi ${ }^{20}$ ve deneyimselliği önemsemiştir. Bu nedenle Franklin'in ahlak anlayışı dine dayalı bir sistem değildir, bireysel olarak insanlara iyilik yapmak üzerinde yükselen ortak iyiliği geliştirmeyi amaçlayan ve bilimin öncü rolünü benimseyen felsefi bir tasavvurdur.

\section{Siyaset ve Franklin}

Franklin'in Amerika tarihi açısından önemi sadece ahlak felsefesi ile ilgili değildir. Belki bundan daha önemli olarak Amerikan siyaseti üzerinde etkili olmuştur. Elbette Franklin açısından bu ahlaki gelişme ve siyaset birbirinden ayrı olarak düşünülemez. Autobiography'de en büyük arzularından birisinin Erdem Sanatı başlığı altında erdemli olmanın araçlarını ve yöntemlerini göstermeyi amaçlayan bir kitap yazmak olduğunu belirtir (Franklin, 2004: 75). Bu arzusuna rağmen Franklin bu kitabı yazmayı ve yayımlamayı başaramamıştır. Siyaset anlayışı açısından bakıldığında Franklin'in siyasal düşüncesi ilerleme ve civic iyileşme nosyonlarına yaslanır. Bu açıdan onun siyaseti sürekli kendini düzeltmeyle işleyen bir deneyim sürecini ifade eden Baconcu bir yaklaşıma sahiptir (Smith, 2016: 124). Franklin'in gerek ahlak gerek siyaset anlayışında anahtar kavram iyileşmedir (improvement). İyileşme köken olarak tarım alanlarının kârlı bir biçimde işletilmesi anlamına gelen tarımsal bir kavramdı. 17. Yüzyılla birlikte büyüme, gelişme veya mükemmelleşme gibi toplumsal ve siyasal reformları içeren bir anlama sahip oldu. Kavram siyasal iktisat temelli olmasına rağmen, sadece ekonomik bir içeriğe sahip değildir. Bilgi arayışı, dostlukların geliştirilmesi, özgürlüğün korunması ve ihtiyaçların giderilmesi gibi anlamları da içerir. Bu açıdan iyileşme ve medenileşme süreci neredeyse özdeş bir hale gelir (Houston, 2008: 12).

Franklin'in politik düşüncesinin bulunabileceği ilk metinler "Sessiz İyilik" mahlasıyla kaleme aldığı yazı serileridir. Franklin bu metinlerden birisinde Cato'nun London Journal'da yayımladığı metni uzun bir biçimde alıntılar ve

\footnotetext{
${ }^{20}$ Franklin'in pragmatizm ile ilgili eserleri şunlardır: Plain Truth (1747,

https://founders.archives.gov/documents/Franklin/01-03-02-0091), Observations Concerning the Increase of Mankind (1751, https://founders.archives.gov/documents/Franklin/01-04-02-0080), Causes of the American Discontents before 1768 (1768, https://founders.archives.gov/documents/Franklin/01-15-02-0001), An edict by the King of Prussia (1773, https://founders.archives.gov/documents/Franklin/01-20-02-0223) ve 1790 tarihli Sidi Mehmet ibrahim ve köle ticareti üzerine bir makale (1790, Benjamin Franklin to the Federal Gazette (unpublished), http://franklinpapers.org).
} 
buradaki ifadeleri kendi düşüncesi olarak sahiplenir. Buna göre, düşünce ve ifade özgürlüğü olmaksızın bilgelik ve kamusal özgürlükten söz edilemez. Başkasına zarar vermediği müddetçe her insan bu özgürlüğe sahiptir ve bu bir haktır. Bu hak aynı zamanda tüm özgür yönetimlerin temelini olușturur. Mülkiyetin güvence altına alınması ifade özgürlüğü ile mümkün olur. Yöneticilerin faaliyetlerinde yaptıkları hataları duymak istememesi ancak tiranlara özgü bir ayrıcalıktır.

Özgür insanlar ise sadece ifade özgülüğünü kullanarak özgür olduklarını gösterebilirler. Hükümetler halkın çıkarlarını gözetmek için halkın temsilcileriyle faaliyetlerini yürütürler. Yönetimin işlemleri halk tarafından gözlemlenir ve kontrol edilir. Sadece kötü yönetimler bu süreçten korkarlar. Ifade özgürlüğü iyi bir yönetimin hem bir işareti hem de bir sonucudur. Bu nedenle sadece suçlular ifade özgürlüğünden korkarlar (Franklin, 1722a). Benzer biçimde özgürlük ve güvenlik denkleminde Franklin oldukça açık bir tercihte bulunur. Ona göre, geçici bir güvenlik için temel özgürlükleri terk edenler sonunda ne özgürlüğe ne de güvenliğe sahip olacaktır (Franklin, 1755). Franklin bir diğer makalesinde keyfi yönetimin ve sınırsız iktidarın düşmanı, ülkesinin hakları ve özgürlükleri konusunda da oldukça titiz olduğunu belirtir (Franklin 1722C).

Buradaki dikkate değer bir konu yukarıda belirtilen din ve ahlaki reformun önemidir. Franklin bir cumhuriyete dine yönelik ikiyüzlü iddia sahiplerinin mi yoksa sekülerlerin mi zarar verdiğini kendisine sorar ve yanlış ifade edilmiş bir dinin cumhuriyete daha çok zarar vereceğini savunur (Franklin, 1722d). Bununla birlikte Franklin özerklik ve bunun için gerekli erdemlere insanların doğal olarak sahip olmadığının farkındadır. Özgürlük ruhunun ve özerklik yetisinin öğretilebileceğini savunur. İnsan kendi maddi refahının sorumluluğunu üstlendiğinde bunun sağladığı özgürlüğe değer verecektir ve özgüven kazandıktan sonra da daha büyük sorumluluklara sahip olacaktır. Bireylerin dürüstlük, nezaket ve dürüstlüğün değerini öğrenmeleri daha büyük teşebbüsler için onları hazır hale getirecektir. Böylece kişisel-çıkar feda edilmeksizin, bireyler ortak iyi için sıkı bir şekilde birbirine bağlanmış olur. Franklin'in bu bakış açısı bir orta sınıflaşma talebidir. Zaten siyasal meselelerde orta sınıfların tercümanı olmaya çaba göstermiş ve hem ayaktakımının hem de yerleşik ayrıcalıkların düşmanı olmuştur (Pangle, 2007:21-2). Bu nedenle Franklin insanların bağımsızlığı ve ekonomik özgürlüğü ile maddi hayatlarında iyileşmenin önemi üzerinde özellikle durur. O dönemde iktisadi düşünce ağırlıklı olarak merkantilizm tarafından biçimlense de Franklin bu yaklaşımın adaletsiz ve basiretsiz olduğunu düşünmüş, serbest ticaretin ve ekonomiye devlet müdahalesinin asgariye indirilmesinin ilk savunucularından birisi olmuştur (Pangle, 2007:29-30). Merkantilizme bu dönemde karşı çıkılmasındaki etkenlerden birisi ihracat odaklı iktisadi faaliyetin tarım ekonomisini baltaladığının düşünülmesi idi. Serbest ticareti savunanlar geniş orta sınıfların refahı için tarım ekonomisinin önemini vurguluyorlardı. Bu açıdan sanayi devrimi ve bu dönemin liberalizminin ekonomi politikaları açısından 18. Yüzyıl Aydınlanma hareketinin doğrudan bir devamı olup 
olmadığı dikkat çekici bir durumdur. Bununla birlikte, Thomas Jefferson'dan farklı olarak, Franklin iyi bir cumhuriyetin özgürlük ruhunun, kadere bağımlı çiftçilerden ziyade aklın rehberlik ettiği müteşebbis karakterler üzerinden inşa edileceğini düşünmüştür. Diğer bir ifadeyle, akıl, talihe galip gelebilirdi ve böylece ilerleme ve umut için bir alan açılmış olmaktaydı. Bu nedenle Amerikan ahlak felsefesinin bir göstergesi olarak aydınlanmış kişisel-çıkar, kendiliğinden değerli bir niteliğe değil, faydalılığını sürekli gösteren bir erdem anlayışana gönderme yapar (Pangle, 2007:50).

Franklin'in özgürlük anlayışı erdem ile doğrudan ilişkilidir. Ona göre, "Sadece erdemli bir halk özgürlüğe sahip olabilir. Uluslar yozlaştıkça ve ahlaklarını yitirdikçe, onlar efendilere daha çok ihtiyaç duyarlar.” (Franklin, 1787). Yine benzer bir biçimde Poor Richard'da" şunu ifade eder: “Erdem yoksa özgürlük de yoktur. Bu bir cumhuriyette olduğu kadar özel şahıslar için de bir şiardır." (Franklin, 1739). Bu açıdan Franklin'in özgürlük anlayışı ile yukarıda ifade edilen ahlaki reform ve erdemlerin geliştirilmesi arasında doğrudan bir bağlantı bulunmaktadır. Bu ahlaki reform ve özgürlük anlayışlarının somut göstergelerinden birisi Franklin'in yaşam boyu sürdürdüğü tutkusu olan gönüllü faaliyetler ve hayırsever projelerdir. İnsan aklının aydınlanmacı bir paradigmayla bu şekilde kendisine bir alan açması kolektif ve iletişimsel bir eylem dünyası oluşturur (Kelleter, 2008: 85). Franklin'in sahip olduğu bu projeci ruh başlıca Daniel Defoe'nin Essays on Projects (1697) ve Cotton Mather'in Bonifacius, or An Essay upon the Good (1710) adlı kitaplarından ilham almıştır. Zihnindeki temel mesele yapılacak ‘'yi şey nedir?’ sorusu olmuştur. Bu anlamda Franklin'in partizanlığı aşmaya teşebbüs eden ilk demokratik özerklik deneyimi iletişime, müzakereye ve kitaplara daha kolay erişim sağlamak amacıyla 1727 yılında Junto'nun kurulması olmuştur. ${ }^{22}$ Franklin özellikle ahlak ve siyasetteki öğrenme iştahını yansıtan bu projeyi tasarladı, üyeleri seçti, kuralları oluşturdu, haftalık tartışmalar için konuları belirledi. Bir akademiye dönüşen Junto'nun etkinliliğini artırmak için, Franklin arkadaşlarını kitaplarını ortak kullanıma açmaları için ikna etmeye çalıştı. Gayr-i resmi bir kütüphaneye dönüşen bu yapının yeterince iyi işlemediğini düşünen Franklin, resmi bir üyelikle oluşacak bir yapı tasarladı ve bu da kolonilerdeki üyelikle çalışan ilk kütüphane olan Philadelphia Kütüphane Topluluğu'nun kurulmasıyla sonuçlandı. Bu sırada Junto'nun kuruluşundan sonra Pennsylvania Gazette’yi çıkarmaya başladı (Pangle, 2007:93, 98-9). Aynı gazetede Apology for Printers başlığıyla yayımladığı bir makalede matbaacıların neden her türlü düşünceyi yayımlamaları gerektiğini ortaya koyar. Ona göre, ne kadar insan

\footnotetext{
${ }^{21}$ Bu noktada şunu da ifade etmek mümkündür. Franklin'in bizatihi bu almanakları erken dönem Amerikasında yüksek ve popüler kültür arasında bir bağ kurmuştur. Sıradan insanlar ve elitler arasında bir dolaşıma imkân vermiş, bilimsel, edebi ve tarihsel bilginin halka ulaşmasını sağlamıştır. Böylece sağlıklı bir kamusal alanın oluşmasına hizmet etmiştir (Pencak, 2011: 288).

22 Junto, Birleşik Erdem Partisi olarak adlandırılacak ve "tüm ulusların erdemli ve iyi insanlarını" düzenli bir yapı içerisinde bir araya getirmeye çalışacaktı. Franklin'in bu oluşumu Aydınlanmanın Republic of Letters (Aydınlar Cumhuriyeti) veya İnsanlık Partisi tasavvurunu bir açıdan somutlaştırır. Bu partinin amacı sadece hakların korunması değil aynı zamanda civic ilerlemenin sağlanmasıdır. Amaçlara ulaşabilme böylece şiddet içermeyen bir ikna ve müzakere ile sağlanmış olacaktır (Smith, 2016: 125-6).
} 
varsa o kadar zihin vardır ve bu zihinlerden ortaya çıkan düşünceler doğal olarak lehte veya aleyhte olabilir. Kamuoyu, insanların bu düşünce farklılıklarını duyma hakkına sahiptir. Doğrular ve yanlışlar adil bir biçimde ortaya konulduğunda doğru her zaman yanlışa galip gelecektir. Bununla birlikte, matbaacıların yayımladıkları her şeyi onayladıkları düşünülmemelidir. Diğer taraftan, matbaacıların onayladıkları şeyler dışındaki konuları yayımlamaması gerektiği düşüncesi akla aykırı olacaktır (Franklin, 1731).

Franklin'in Autobiography'si ya da onun Junto'nun kuruluşuyla gerçekleştirdiği deneyimler aynı zamanda cumhuriyetçilik bağlamında okunabilir. Erdeme takıntılı bir figür olarak Franklin'in, erdemin pratiği, başarısı ve sonuçlarıyla ilgilendiği görülmektedir. Erdeme yönelik bu vurgunun bir diğer boyutu da doğru davranışın ne olduğunu göstermektir. Bu açıdan bakıldığında Franklin cumhuriyetçi siyasal düşüncenin ahlak teorisini ve pratiğini ortaya koymaktadır. Çünkü cumhuriyetçi siyasal teori bir bakımdan erdemli ve özverili yurttaşların ortak refahın geliştirilmesine adanmalarını ifade eder. Franklin bu fikirleri kucaklamıştır ve farklı sivil toplum örgütlenmeleriyle bu fikirleri gerçekleştirmeye çalışmıştır (McCarthy, 2003: 16). Franklin'deki bu erdemlilik vurgusu ile düşünce ve ifade özgürlüğünün sözü edilen merkezi konumu aynı zamanda Franklin'in devlet anlayışının ne olduğunu gösterir. Hâkimiyetin temelini düşünce olarak gören Franklin bu anlayışılyla Lockçu meşru yönetimin halkın rızasıyla oluşturabileceği ve Humecu bütün yönetimlerin düşünceye dayandığı önermelerini onaylar. Bu nedenle ona göre sağduyulu devlet yöneticileri düşüncelerin gücünü dikkate almak zorundadır (Pangle, 2007:141-2). 1769 tarihinde yazdığı bir mektupta Franklin şunları ifade eder: "Devlet sadece güçle kurulmamıştır; onu sağlam ve dayanıklı kılmak için bilgelik ve adalet genel görüşü ile sürdürülmelidir” (Franklin, 1769a). Franklin'in siyasal düşüncesini tamamlayan bir diğer unsur yaratılışından gelen hiyerarşiden hoşlanmama ve otoriteye karşı çıkma eğilimiydi. Bu eğilim döneminin koşulları içerisinde onu daha eşitlikçi yapmıştı. Mesela Pennsylvania Üniversitesi için ortaya koyduğu tasavvur (Thomas Jefferson'un Virgina Üniversitesi'ni daha çok toplumsal liderlerin ortaya çıkmasını amaçlayan bir merkez olarak tasarlamasından farklı olarak) burasının bir elit eğitim merkezi değil bütün azimli gençlere fırsat sunan bir ortam olmasıdır (Isaacson, 2014: 148).

\section{Franklin'in Algılanıșı}

19. yüzyılın başlarında ve ortalarında yazılan bazı biyografilerde Franklin rekabetçi piyasa ekonomisinin taleplerini karşılayan bir figür olarak sunulmuştur. Buna göre, Autobiography finansal ve toplumsal başarılarıla babacan ve kendikendini inşa eden bir yaşam öyküsü sunar (Arch, 2008: 167). Franklin'in bu yaşam hikâyesi, daha önce bahsedildiği üzere, Amerikan başarı anlatııının ilk büyük örneği olarak okunur. Bu açıdan Franklin 19. yüzyıl piyasa toplumunun ihtiyacını karşılayan bir rol model olarak düşünülmüştür ya da diğer bir ifadeyle 19. yüzyıl piyasa toplumu için bir Franklin karakteri inşa edilmiştir. 
19. yüzyılda yaşamış Fransız gazeteci ve eleştirmen Charles Augustin Sainte-Beuve gibi romantikler ise ruh, tutku ve erosun iç dünyasını kavramakta başarısız olduğu için Franklin'i Aydınlanmanın büyük sadeleştiricisi olarak görmüşlerdir. Buna göre, Franklin yaşama yönelik pratik tutumu nedeniyle ruhun daha derin ve daha gizemli bölgelerini tahayyül edememiştir. Franklin'in bu basitliği ayrıca Fransa'daki dostlarının devrim ütopyası peșinde koşmalarını sağladığından, Sainte-Beuve, Fransız Devrimi'nin arkasında Franklin'in felsefesi olduğunu iddia eder (Smith, 2016: 111).

D. H. Lawrence Klasik Amerikan Edebiyatı Üzerine Çalışmalar başlıklı eserinde Franklin'e iyi bilinen bir eleştiri getirir. ${ }^{23}$ Bu yoruma göre, Franklin'in temsil ettiği finansal ve toplumsal başarı düşüncesi, para kazanma arzusu bir duygu ve ruhtan yoksundur (Arch, 2008: 168). Lawrence bunu şöyle ifade eder: “Franklin'e neden tahammül edemediğimi en azından şimdi anlıyorum. 0 bütünlüğümü, karanlık ormanımı yani özgürlüğümü ortadan kaldırmaya çalışmaktadır. Sınırsız bir geçmiş olmadan insan nasıl özgür olabilir? Benjamin beni dikenli tellerle çevrili bir otlak arazisine tıkıştırmaya ve orada patates gibi yetiştirmeye çalışıyor." Buna göre, Lawrence, Franklin'in ahlaki mükemmelliğe ulaşma projesini "ahlakın dikenli tellerle kapanması" olarak tasvir eder. Ona göre, "Insan ruhu geniş bir ormandır, Benjamin'in tüm istediği ise düzenli bir arka bahçedir." 24 Franklin böylece hayatın kendiliğindenliğini, iradenin mekanik dünyasına tabî kılıyor ve bir açıdan yaşamı otomatik bir makineye dönüştürüyordu. Franklin'in bunu yapmasının nedeni ise, Lawrence'e göre, ilk olarak tamamen insan huysuzluğudur. Franklin İngiltere'den, Avrupa'dan nefret ediyordu ve bir Amerikalı olmak istiyordu. Böylece geçmişi alaşağı etmeyi amaçlıyordu (Lawrence, 1923). Lawrence, Franklin yorumlarını büyük ölçüde Autobiography'ye ve Poor Richard's Almanac'a dayandırmaktaydı. Bu nedenle Franklin'in diğer metinlerini ihmal etmiştir ve onu sadece "Amerikalı" olmayı arzulayan bir figüre indirgemiştir (Houston, 2004: xv).

Franklin yeni kapitalist düzenin ve onun zenginlik arzusunun tipik bir örneği olarak görülmüştür. Marx'ın (2011: 318) ifadesiyle, “Aristo'nun tanımı, tam olarak, insanın doğası gereği kent yurttaşı olduğudur. Franklin'in, insanın doğası gereği alet yapan hayvan olduğu seklindeki tanımı Yankee'ler için ne kadar karakteristik ise, bu tanım da klasik Eski Çağ için o kadar karakteristiktir." ${ }^{25}$ Marx'ın burada Franklin'in erdemlerini Yankeelik olarak değerlendirdiği tartışma daha sonrasında Max Weber'in Protestan Ahlakı ve Kapitalizmin Ruhu adlı eserinde tekrar gündeme gelmiştir. Weber bu kitabında Kapitalizmin Ruhu

\footnotetext{
${ }^{23}$ Wood'a (2004: 8) göre, Franklin'e yapılan şu ana kadarki en ünlü eleștiri budur.

${ }^{24}$ Lawrence ile benzer argümanlar Amerikan edebiyatında daha sonraları da devam etmiștir. Edgar Allan Poe'nun The Businessman (1840), Herman Melville'nin Israel Potter (1855) ve Mark Twain'in The Late Benjamin Franklin (1870) adlı eserleri örnek olarak gösterilebilir (Arch, 2008: 168).

25 Benzer Yankee'lik vurgusu, Amerika çalışmalarında bir diğer yorumlama biçimi olan Büyük Uyanış’ın öncü teologlarından birisi olan Jonathan Edwards'ın temsil ettiği “Püriten” eğilim ile Franklin'in temsil ettiği “Yankee” kutuplaşması bağlamında görülebilir. 18. Yüzyııın Amerikan zihin dünyasını temsil eden bu iki yaklaşım Amerikan kültüründe yerleşik bir paradoks olarak değerlendirilmiştir (Oberg, Stout, 1993: 4).
} 
başlıklı bölümde “kapitalizmin 'ruhu'ndan ne anlaşıldığını” (Weber, 1999: 41) göstermek amacıyla Franklin'den yaklaşık üç sayfalık uzun bir alıntı yapar. Bu alıntının "klasik saflığı içeren" ve aynı zamanda "din ile ilgili bütün doğrudan ilişkilerden” bağımsız olduğu için “ön yargılardan” kurtulma imkânı sağladığını belirtir. Bu alıntıda Weber temel olarak Franklin'in şu cümleleri üzerinde durur: "Unutma ki zaman paradır. ... Unutma ki kredi paradır. ... Unutma ki para, üretimi güçlendirici ve verimli bir yapıya sahiptir. Para parayı üretir ve ondan elde edilen daha fazlasını ve daha fazlasını üretebilir. ... iyi bir ödeyici, herkesin cüzdanının efendisidir. ... söz verdiğin gibi, ödünç parayı gereğinden bir saat bile fazla elinde tutma ki arkadaşının kızgınlığı, bütün bütün cüzdanının ağzını kapamasına neden olmasın. ... Borçlarına sadıksan, bu durum senin şerefli bir insan olduğun gibi sorumlu biri olduğunu da gösterir; bu da senin kredini arttırır. Sahip olduklarını kendi mülkiyetinde tutmaya ve ona göre yaşamaya dikkat et." ${ }^{26}$ (Weber, 1999: 41-43). Weber, Franklin'in bu ifadeleriyle özgün bir biçimde kapitalizmin ruhunu dile getirdiğinden emindir ve bu düşüncelerin bir yaşama tekniği olmadığını, özel bir "ahlak” anlamına geldiğini savunur. Burada açığa çıkan ethos "ticari zekânın", kendinde bir değer olarak daha fazla para kazanmanın, rasyonel biriktirmenin ve kazanma görevinin öğretilmesidir. Daha fazla para kazanma doğal ve kendiliğinden bütün yaşam zevklerinden kaçınmayla sonuçlanacaktır. Weber'in anlayışında Franklin'in bütün ahlaki yaklaşımları yararcılığa dönüşmek durumundadır. Bu nedenle şerefli olmak, dakiklik, çalışkanlık, ölçülülük kredi sağladığı için yararlı görülürler. Bu nedenle üretimi artırmayan nitelikler yararsız olurlar (Weber, 1999: 45). Weber (1999: 130) ayrıca kapitalizmi dünyaya içkin bir asketizm olarak tanımlar ve Franklin'in bu yaklaşımı temsil ettiğini ileri sürer. ${ }^{27}$ Büyük bir ihtimalle Weber'in Franklin'de en çok hakir gördüğü unsur onun herhangi bir anlamda ahlaki görev nosyonundan yoksun olmasıydı. Weber etik anlayışında sıkı bir Kantçı olduğu için görev, ahlak ve zorunluluk gibi kavramların fayda, haz ve mutluluk gibi kavramlardan esaslı bir biçimde ayrı tutulması gerektiğine inanmaktaydı. Ona göre, görev kendinde bir

\footnotetext{
${ }^{26}$ Weber tezlerini ileri sürerken temel olarak Franklin'in Yaşlı Bir Tüccardan Genç Bir Tüccara Tavsiye (Advice to a Young Tradesman, Written by an Old One, 1748) başlıklı makalesini kullanmıștır. Ayrıca Poor Richard's Almanack'larından seçmeler yapmıştır. Bu metinler Franklin tarafından kısmen ticarete yeni başlayanlar ve okuma yazması zayıf kırsal bölge halkı için yazıımıştır. Weber bu metinlerden yola çıkarak çoğunlukla haz almaksızın sıkı çalışma ve biriktirme üzerinde durur. "Zenginlik ona sahip olmak değil, onun keyfini çıkarmaktır”, "O zenginliğe sahip değil, zenginlik ona sahip olmuş" gibi Poor Richard's metinlerindeki bazı ifadeleri dikkate almamıştır (Pangle, 2007:17-9). Bu nedenle Weber'in Franklin hakkında yeterince kaynak kullanmadığı belirtilebilir.

Bkz. B. Franklin (1748), Advice to a Young Tradesman, Written by an Old One

https://founders.archives.gov/documents/Franklin/01-03-02-0130; Franklin'in Poor Richard's Almanack yazı dizileri için bkz. http://franklinpapers.org/

${ }^{27}$ Franklin Autobiography’ye kendisine Benjamin Vaughan'dan gelen bir mektubu dahil eder. Vaughan şunları ifade etmiştir: "Son olarak hayatınızın sırf bir biyografi örneği olarak kullanılmasını gösterecek bir düşünce var efendim. Bu yazı stili biraz modası geçmiş gibi görünüyor ve yine de çok kullanışlı bir yazı. Bir takım bilinen canilerin ve düzenbazların hayatlarıyla, saçma sapan manastıra özgü kendi kendine işkence edenlerle karşılaştırıldığında sizin örneğiniz özellikle kullanışlı olabilir. Sizinle benzer türde daha fazla yazı yazmayı cesaretlendiriyorsa ve daha fazla insanı yazılacak bir yaşam sürmeye teşvik ediyorsa bir araya getirilen tüm Plutarch'ın Lives'ına değecektir." (Franklin, 2004: 62). Metin üzerinde vurgulandığı (şahsım tarafından) üzere, Weber'in Franklin’i asketik kapitalizmin öncüsü olarak tanımlamasından farklı olarak, Franklin'in kendi zamanında nasıl göründüğüne ilişkin kanaati farklıdır.
} 
amaç olduğu için bu görüşten uzaklaşan ne olursa olsun ahlaki olarak değerlendirilemez (Smith, 2016: 112). Bir diğer açıdan, Moses'a (2008: 132) göre, Weber, Franklin'in neşeli imajını kurnazca değiştirip, Poor Richard'ı Ebenezer Scrooge'a $^{28}$ dönüștürür. Weber'in esas amacı, Batı Avrupa'da ve Kuzey Amerika'da kapitalizmin yükselişine sosyolojik bir açıklama yapmaktı. Protestan ahlakının Martin Luther ve John Calvin'in takdir-i ilahi doktrininden ortaya çıktığını savunmaktaydı. Buna göre, her şeyi bilen tanrı her ruhun kaderini biliyorsa, bazıları için kurtuluşu, bazıları için de lanetlenmeyi önceden tasarlamış olmalıydı. Bu teori doğal olarak kadercilikle sonuçlanacaktı. Ancak gerçek dünyadaki Protestanlar varsayıldığı gibi kaderci görünmüyorlardı. Bir sosyolog olarak Weber canlı burjuva kültürünün Kalvinist kendini-inkâr ve kaderci bir anlayış üzerinde nasıl ortaya çıktığını açıklamaya teşebbüs etmekteydi. Bu nedenle, Franklin'i bu iki karşıt durumun nasıl birleştirilebileceğini göstermek için kullanmıştır. Yukarıda belirtildiği gibi Franklin'in ahlak anlayışının summum bonum'unu daha fazla para kazanma ve hayatın doğal zevklerinden uzaklaşma olarak tasvir etti. Oysaki, Weber, Franklin'in 42 yaşında iş hayatından emekli olduğunu ve bu yaştan sonra hayatını civic faaliyetlere ve bilimsel çalışmalara adadığını ihmal etmiştir ${ }^{29}$ (Moses, 2008: 132-3). Daha da dikkat çekici bir durum, Protestan ahlakını kapitalizmin ruhuna bağlarken herhangi bir Protestan'ın sözlerine değil, "renksiz bir deist" (Weber, 1999: 46) ) $^{30}$ olarak tanımladığı Franklin'e başvurmasıdır (Moses, 2008: 136).

Para kazanma ve burjuva değerlerinin bir sözcüsü olarak Franklin'in yanında bir başka Franklin gerçekliği de söz konusudur. 1750 yılında yazdığı bir mektupta bir amacı olmaksızın zenginlik peşinde gidenlerle alay etmiştir ve bunu saçma bulmuştur (Franklin, 1750a). Yine bir diğer mektubunda hakkında zengin bir insan olarak öldü denilmesini değil, faydalı bir hayat yaşadı denmesini tercih edeceğini belirtir (Franklin, 1750b). Diğer taraftan siyasette paranın istismar edilmesine karşı sürekli uyarılarda bulunmuş, devlet görevlilerinin herhangi bir ücret almadan hizmette bulunmalarını teşvik etmiştir (Wood, 2004: 9). Hayatının son otuz yılının büyük çoğunluğunu Amerika dışında, Britanya ve Fransa'da, geçirmiş birisi olarak Franklin'in tipik bir kapitalist ve para kazanma peşinde koşan biri olarak değerlendirilmesi kolay değildir. 1748 yılında ticari hayattan çekildiğinde arzu ettiği kamusal imajının bir tüccar değil, beyefendi bir aristokrat olmasıydı. Kendi ifadeleriyle, "özel işlerden ayrıldığımda ... hayatımın geri kalanında felsefi çalışmalar ve eğlencelerle ilgilenebilecektim” (Franklin, 2004:

\footnotetext{
${ }^{28}$ Ebenezer Scrooge, Charles Dickens'ın Bir Noel Şarkısı (1843) adlı romanındaki başkarakterdir. Bu karakter tefeci bir iş adamıdır ve pintiliğiyle bilinir.

${ }^{29}$ Moses'a göre, Thorstein Veblen'in Aylak Sınıfının Teorisi (1899) adlı kitabı Franklin'e önemli bir sembolik rol vermese de Yaldızlı Çağ’ın (Gilded Age, 19. Yüzyılın ikinci yarısı) Amerikalı kapitalistlelerini Weber'den daha iyi anlamıştır. Buna göre, bu çağ kendilerini her ne kadar kamu görevlisi olarak sunsalar bile aslında gösterişçi tüketicilerle biçimlenmiştir. Veblen'e göre, Batı ekonomileri tutumlulukla değil, zenginliğin gösterişçi tüketimiyle hareket etmektedir. Bu nedenle Veblen'in teorisi Weber'in teorisiyle uzlaştırılamaz. Weber kapitalizmin ruhunu tasarruf adına yapılan bir tasarruf olarak görürken, Veblen onun harcama adına yapılan bir harcama olduğunda Israr eder (Moses, 2008: 138-9, 141).

${ }^{30}$ Kaynak gösterilen Weber'in Türkçeye çevrilen kitabında deist ifadesi mümin olarak çevrilmiştir.
} 
100). Bu felsefi çalışmalar ve eğlenceler arasında Franklin'in aklında elektrik üzerine deneyler yapmak vardı ve bu deneylerin bir kısmını gerçekleştirerek takdir kazandı. Joseph Priestley, Isaac Newton'dan beri büyük bir ihtimalle en büyük keşiflerin Franklin'e ait olduğunu belirtir. Kant ise Franklin'i ateşi göklerden çalan modern bir Prometheus olarak tanımlar (Wood, 2004: 65). Diğer taraftan, Franklin'in biyografisinde görüleceği üzere o aklı, sosyalliği, kamu hizmetini ve yardımseverliği takdir etmiştir. Kütüphaneleri, kolejleri ve çeșitli toplumsal projeleri desteklemiştir. Tüm bu projelerdeki amacı bilginin geliştirilmesi ve bunun da ortaklıklarla ve mübadele ile gerçekleştirileceğinin farkında olması söz konusudur. Onun felsefesi bu açıdan Francis Bacon'ın düşüncelerinin halk için uyarlanmasıdır; yani ampiriktir, deneyimseldir ve pratiktir. Sıradan insan için bir Aydınlanma arayışıdır. Weber ve başkalarını bu açıdan rahatsız eden konu Franklin'in Aydınlanma anlayışının katı bir biçimde eşitlikçi olmasıdır. Görünüşte herhangi bir avantaja sahip olmayan bir kişinin tümüyle kendi-kendini eğiterek nasıl ulusal ve uluslararası bir üne kavuştuğunu gösterir (Smith, 2016: 129). Bunun yanında Franklin'in bir burjuva ahlakıyla mı yoksa Weber'in alıntı yaptığı metinlerin bir açıdan muhatabı olarak düşünülebilecek insanlar dikkate alındığında toplumun alt ve orta sınıflarına mı tavsiyelerde bulunduğu dikkat çekici bir konudur. Franklin'in toplumun geniş orta sınıflarının ekonomik olarak özgürleşmesini amaçladığı ifade edilebilir. Böyle düşünüldüğünde Franklin'in tipik bir kapitalist olarak değerlendirilmesi kolay olmayacaktır. 1776 yılında yazdığı bir metinde mülkiyet haklarını tanımakla birlikte, bu hakkın doğal sınırlarına bir vurgu yapar: “Mülkiyetin büyük kısmının birkaç bireyin elinde olması haklara zarar verir, insanlığın ortak mutluluğu için yıkıcıdır. Bu nedenle, her özgür eyalet böyle bir mülkiyetin sahiplenilmesini engellemek için yasalar tarafından verilen bir hakka sahiptir." (Franklin, 1776). Bir başka yazısında ise toplumların zenginleşmesi üzerinde durur: "Bir ulusun zenginleşmesinin üç yolu vardır. illki Romalıların fethettikleri komşularını yağmalamalarında olduğu gibi savaştır. Bu soygunculuktur. İkincisi ticarettir ve genellikle aldatıcıdır. Üçüncüsü tek dürüst yol olan tarımdır. Burada insan kendi masum yaşamının ve erdemli çalışkanlığının bir ödülü olarak, sürekli bir mucize gibi ... toprağa attığı tohumların gerçek mahsulünü alır." (Franklin, 1769). Daha da ilginç bir biçimde Franklin işçi sınıfının bir kahramanı olarak görülebilir. 1795 yılında usta ve kalfalardan oluşan New York Genel Mekanik ve Esnaf Topluluğu "kardeş mekanik Benjamin Franklin" için bir kutlama yaparak şunu ifade etmişlerdir: “(Franklin'in) aydınlık örneği bu özgürlük ve eşitlik ülkesinde insanları ikna etsin, hükümetin temel birimlerine adil bir biçimde uygulanması amacıyla tutumlu ve erdem sahibi yetenekleri bir araya getirsin." (Whitehead, 2009: 25).

\section{Sonuç}

Benjamin Franklin popüler kültürdeki neredeyse sempatik bir figüre indirgenen algının ötesinde bir Aydınlanma düşünürü ve siyasetçisi olmuştur. Bu açıdan zamanının değer dünyasını temsil eder. Bu bağlamda Franklin ile ilgili söylenebilecek en genel yargı onun tatmin olmaz bir merak duygusuna sahip 
olmasıdır. Bu merak duygusunun alanı ise doğa bilimi araştırmalarından dini, politik ve felsefi tartışma alanlarına kadar oldukça geniştir. Elbette Franklin sistematik bir filozof veya siyaset teorisyeni değildir. Geniş bir alana yayılan ve oldukça parçalı olan metinleri buna izin vermez. Ancak sözü edilen bu ilgileriyle Franklin Amerikan değerlerinin kuruluşunu temsil edebilir. Bununla birlikte, söz konusu bu konumlanışı sanayi devrimi ve sonrası ortaya çıkan iş insanı ve çıkarları peşinde giden bir varlık olarak birey anlayışını yeterince açıklamaz. Isaacson'un (2014: 3) belirttiği gibi, Franklin bir orta sınıf savunucusudur. Onun vizyonu orta sınıf değerleri üzerinde inşa edilen bir Amerikan kimliğidir. Bu nedenle bir iyileşme (improvement) dili (kazanç ve kâr, ilerleme ve mükemmellik, artış ve genişleme, fayda ve ıslah) Franklin'in metinlerinin her tarafına yayılmıştır (Houston, 2004: xvii). Franklin ütopya sahibi birisi değildi, realistti, pratik meselelerle ilgilenen gerçekçi bir insandı. İnayetin tanımlanamaz durumları veya dini canlanma peşinden gidenlerin hatırlattığı gibi günahın azap verici halleriyle ilgilenmiyordu (Anderson, 2008: 26). Franklin'in sözü edilen ilerleme nosyonu kaçınılmaz bir biçimde ahlak felsefesinde bir tavır almasıyla mümkün olmuştur. Onun ahlak felsefesi bireysel erdemlerin geliştirilmesi sonucunda kişisel-çıkar ve toplumsal faydanın eklenmesine odaklanmıştır. Franklin'in ahlak felsefesindeki radikal boyut ise kurumsal dini mirasın artık bu ahlaki perspektifte kendisine bir fonksiyon bulamamasıdır. Franklin bu konumuyla Amerikan Aydınlanmasının ve Amerikan karakterinin temel bir inşacısı rolüne sahiptir. Ancak bu okuma biçimi Amerikan Aydınlanmasında karşımıza çıkan bir diğer yaygın eğilim olan Jonathan Edwards üzerinden temsil edilebilecek Kalvinizm içerisinde gelişen Amerikan Püritenliğinin ihmal edilmesiyle sonuçlanmamalıdır. Edwards, Kalvinizme karşı çıkmaktan ziyade aksine onu takviye ederek 18. yüzyılın Büyük Uyanış hareketinin başlıca sözcülerinden birisi olmuştur. Bu açıdan bakıldığında 18. yüzyıl Amerika'sının iki öncü zihni olan Franklin ve Edwards aynı zamanda ahlak felsefesi ve dini canlılık olmak üzere Amerikan Aydınlanmasının iki eğilimini temsil ederler. Bununla birlikte, Edwards'ın felsefi ve teolojik pozisyonunun, kullandığı kavramsal çerçevenin ve zihinsel dönüşümünün Franklin'in temsil ettiği yeni Amerikan karakterini dışladığını iddia etmek mümkün değildir. Aralarında belli ölçülerde yakınsamalar bulunmaktadır. Nihayetinde Edwards 18. yüzyılın getirdiği değerler dünyasının karşısında değil, onlarla yüzleşerek dini canlanmasının sağlanmasının kaygısını taşımaktaydı.

Son olarak üzerinde durulması gerekli bir konu Franklin'in Amerikan siyasal düşünce tarihi içerisinde başlıca iki yaklaşım olan cumhuriyetçilik ve liberal eğilimlerin neresinde bulunduğudur. Franklin müstakil olarak bu iki siyasal düşünce geleneği içerisinde yer almaz. Houston'ın (2004: xvi) ifade ettiği gibi ne klasik cumhuriyetçidir ne de Lockeçu liberaldir. Bununla birlikte, erdemler üzerindeki vurgusuyla ve ülkenin savunulması konusunda gösterdiği tavırlarla Amerikan cumhuriyetçiliğini etkilemiştir, özgürlükler konusundaki tavrıla da ifade özgürlüğü, hoşgörü ve serbest ticaret gibi birçok liberal temaya sahip olmuştur. Bununla birlikte, liberallerden farklı olarak mülkiyet haklarını doğal 
olarak görmemiştir, cumhuriyetçilerden farklı olarak da iyi bir yurttaşın tümüyle cumhuriyete adanmak zorunda olduğunu düşünmemiştir (Houston, 2008: 220). $\mathrm{Bu}$ nedenle Franklin saf olarak ne Amerikan cumhuriyetçiliğinin ne de liberalizminin temsilcisidir. Açıkçası siyasal düşünce tarihi bağlamında bu iki yaklaşım arasındaki ayrımlar görece olarak Aydınlanma sonrasında açık bir biçimde oluşmuştu. Franklin'in zamanında veya daha genel bir ifadeyle Amerikan Aydınlanmasında bu iki siyasal eğilim belli ölçülerde iç içe geçtiğinden Franklin'in bu iki siyasal düşünceden hangisi içerisinde yer aldığını tartışmak anakronik bir duruma düşme ihtimali doğurur. Franklin kurucu bir figür olarak gerek ahlak felsefesi gerekse de siyasal düşüncesiyle Amerikan cumhuriyetçiliğinin ve liberalizminin gelişiminde etkili olmuştur, ancak bu iki siyasal düşünceden herhangi birine indirgenmesi olanaklı değildir.

\section{Kaynakça}

Anderson, D. (2008). The Art of Virtue. C. Mulford (Ed.). The Cambridge Companion to Benjamin Franklin içinde (ss. 24-36). Cambridge: Cambridge University Press.

Arch, S. C. (2008). Benjamin Franklin's Autobiography, then and now. C. Mulford (Ed.). The Cambridge Companion to Benjamin Franklin içinde (ss. 159-171). Cambridge: Cambridge University Press.

Campbell, J. (2008). The Pragmatist in Franklin. C. Mulford (Ed.). The Cambridge Companion to Benjamin Franklin içinde (ss. 104-116). Cambridge: Cambridge University Press.

Fea, J. (2011). Benjamin Franklin and Religion. D. Waldstreicher (Ed.). A Companion to Benjamin Franklin içinde (ss. 129-145). Oxford: Blackwell.

Franklin, B. (2004). The Autobiography and Other Writings on Politics, Economics, and Virtue. Ed. A. Housten. Cambridge: Cambridge University Press.

Franklin, B. (1790). To Ezra Stiles (unpublished), Philadelphia, March 9, 1790. http://franklinpapers.org/framedVolumes.jsp, Erişim Tarihi: 15 Ocak 2019. . (1787). To the Abbés Chalut and Arnoux (unpublished), Philadelphia, April 17, 1787. http://franklinpapers.org, Erişim Tarihi: 15 Ocak 2019.

.(1776). Revisions of the Pennsylvania Declaration of Rights. https://founders.archives.gov/documents/Franklin/01-22-02-0314, Erişim Tarihi: 15 Ocak 2019. . (1769). Positions to Be Examined.

https://founders.archives.gov/documents/Franklin/01-16-02-0048, Erişim Tarihi: 15 Ocak 2019.

. (1769a). From Benjamin Franklin to Joseph Galloway, 9-28 January 1769.

https://founders.archives.gov/documents/Franklin/01-16-02-0008, Erişim Tarihi: 15 Ocak 2019. 
. (1755). Pennsylvania Assembly: Reply to the Governor, 11 November 1755.

https://founders.archives.gov/documents/Franklin/01-06-02-0107, Erişim Tarihi: 10 Ocak 2019.

.(1750a). From Benjamin Franklin to William Strahan, 2 June 1750. https://founders.archives.gov/documents/Franklin/01-03-02-0192, Erişim Tarihi: 10 Ocak 2019.

.(1750b). From Benjamin Franklin to Abiah Franklin, 12 April 1750. https://founders.archives.gov/documents/Franklin/01-03-02-0189, Erişim Tarihi: 10 Ocak 2019.

. (1749). Poor Richard Improved, 1749.

https://founders.archives.gov/documents/Franklin/01-03-02-0143, Erişim Tarihi: 10 Ocak 2019. .(1739). Poor Richard, 1739.

https://founders.archives.gov/documents/Franklin/01-02-02-0046, Erişim Tarihi: 10 Ocak 2019. .(1735). Dialogue between Two Presbyterians.

https://founders.archives.gov/documents/Franklin/01-02-02-0006, Erişim Tarihi: 10 Ocak 2019. . (1731). Apology for Printers.

https://founders.archives.gov/documents/Franklin/01-01-02-0061, Erişim Tarihi: 10 Ocak 2019. . (1722a). Silence Dogood, No. 8.

https://founders.archives.gov/documents/Franklin/01-01-02-0015, Erişim Tarihi: 10 Ocak 2019. (1722b). Silence Dogood, No. 4. https://founders.archives.gov/documents/Franklin/01-01-02-0011, Erişim Tarihi: 10 Ocak 2019. .(1722c). Silence Dogood, No. 2. https://founders.archives.gov/documents/Franklin/01-01-02-0009, Erişim Tarihi: 10 Ocak 2019. .(1722d). Silence Dogood, No. 9. https://founders.archives.gov/documents/Franklin/01-01-02-0016, Erişim Tarihi: 10 Ocak 2019.

Gaustad, E. S. (2004). Benjamin Franklin: Inventing America. Oxford: Oxford University Press.

Houston, A. (2008). Benjamin Franklin and the Politics of Improvement. New Haven and London: Yale University Press.

.(2004). Introduction. A. Housten (Ed.). Benjamin Franklin: The Autobiography and Other Writingson Politics, Economics, and Virtue içinde (ss. xiii-xxxviii). Cambridge: Cambridge University Press.

Hume, D. (1762). To Benjamin Franklin from David Hume, 10 May 1762. https://founders.archives.gov/documents/Franklin/01-10-02-0043, Erişim Tarihi: 5 Ocak 2019 
Isaacson, W. (2014). Benjamin Franklin (i. H. Yılmaz, Çev.). İstanbul: Türkiye i̇ş Bankası Yayınları.

Jefferson, T. (1853). Notes on the State of Virginia. Richmond: J. W. Randolph.

Kelleter, F. (2008). Franklin and the Enlightenment. C. Mulford (Ed.). The Cambridge Companion to Benjamin Franklin içinde (ss. 77-90). Cambridge: Cambridge University Press.

Kerry, P. (2008). Franklin's Satiric Vein. C. Mulford (Ed.). The Cambridge Companion to Benjamin Franklin içinde (ss. 37-49). Cambridge: Cambridge University Press.

Köktaş, M. (2018). İskoç Aydınlanması ve Liberal Ahlak Teorisinin Temelleri. C. C. Aktan ve B. Şahin (Ed.). Liberalizm, Demokrasi ve Sınırlı Devlet içinde (ss. 127170). Ankara: Orion Kitabevi.

Lawrence, D. H. (1923). Studies in Classic American Literature. http://xroads.virginia.edu/ hyper/lawrence/dhlchoz.htm, Tarihi: 15 Ocak 2019.

Marx, K. (2011). Kapital: Ekonomi Politiğin Eleştirisi I. Cilt Sermayenin Üretim Süreci (M. Selik ve N. Satlıgan, Çev.). İstanbul: Yordam Kitap.

McCarthy, K. D. (2003). American Creed: Philanthropy and the Rise of Civil Society, 1700-1865. Chicago and London: The University of Chicago Press.

Moses, W. J. (2008). Protestant Ethic or Conspicuous Consumption? Benjamin Franklin and the Gilded Age. C. Mulford (Ed.). The Cambridge Companion to Benjamin Franklin içinde (ss. 132-144). Cambridge: Cambridge University Press.

Oberg, B. B., Stout, H. S. (1993). Introduction. B. B. Oberg ve H. S. Stout (Ed.). Benjamin Franklin, Jonathan Edwards, and the Representation of American Culture içinde (ss. 3-9). Oxford: Oxford University Press.

Pangle, L. S. (2007). The Political Philosophy of Benjamin Franklin. Baltimore: The Johns Hopkins University Press.

Pencak, W. (2011). Poor Richard's Almanac. D. Waldstreicher (Ed.). A Companion to Benjamin Franklin içinde (ss. 275-289). Oxford and West Sussex: Wiley and Blackwell.

Smith, S. B. (2016). Modernity and Its Discontents: Making and Unmaking the Bourgeois from Machiavelli to Bellow. New Haven and London: Yale University Press.

Stourzh, G. (2007). Vienna to Chicago and Back: Essays on Intellectual History and Political Thought in Europe and America. Chicago and London: The University of Chicago Press.

Twain, M. (1870). The Late Benjamin Franklin. https://www.gutenberg.org/files/3189/3189-h/3189-

h.htm\#franklin, Erişim Tarihi: 10 Ocak 2019

Weber, M. (1999). Protestan Ahlakı ve Kapitalizmin Ruhu (Z. Gürata, Çev.). Ankara: Ayraç Yayınevi. 
Whitehead, B. D. (2009). Franklin's Way to Wealth. D. Blankenhorn, B. D. Whitehead, S. B. Warren (Ed.). Franklin's Thrift: The Lost History of an American Value içinde (ss. 3-28). West Conshohocken: Templeton Press.

Wood, G. (2004). The Americanization of Benjamin Franklin. New York: The Penguin Press. 